Asy Syar'iyyah: Jurnal Ilmu Syariah dan Perbankan Islam - ISSN 2089-7227 (p) 2598-8522 (e)

Vol. 6, No. 2, Desember 2020, pp. 124--154

\title{
IMPLEMENTASI EARLY WARNING SYSTEM (EWS) DALAM MENEKAN TINGKAT NON PERFORMING FINANCING (NPF) DI PERBANKAN SYARIAH
}

\author{
Novi Febriyanti \\ UIN Sunan Ampel Surabaya \\ novikfbr@gmail.com
}

\begin{abstract}
:
The health of a bank based on sharia principles is in the interest of all parties involved, including the owner, bank management, public users of bank services, Bank Indonesia as the bank supervisory authority and other parties. The following article aims to discuss the principles of Sharia prudential banking through an early warning system (EWS) that Islamic banks usually apply. The research method used is qualitative with a field research approach and literature study with data collection techniques through observation, interviews and documentation. The results show that the application of an early warning measurement system for Islamic banks can be calculated using several indicators, namely including return on equity (ROE), return on assets (ROA), financing to deposit ratio (FDR), non-performing finance (NPF) and ratios. operating costs and operating income (BOPO). This is implemented to reduce the level of problematic financing caused by two factors, namely internal factors (the banking sector), namely the lack of maintenance that has been determined, accuracy in business analysis, understanding of the necessary needs, inclusion of sound policy requirements and pursuing targets. External factors (debtors) are natural disasters, decreased business, collateral, increased competition for business types, low education levels and family factors.
\end{abstract}

Keywords: Prudential Banking, Early Warning System, Non Performing Financing, Bank Health

\begin{abstract}
Abstrak:
Kesehatan suatu bank berdasarkan prinsip syariah merupakan kepentingan semua pihak yang terkait, baik pemilik, pengelola (manajemen) bank, masyarakat pengguna jasa bank, Bank Indonesia selaku otoritas pengawasan bank maupun pihak lainnya. Artikel berikut bertujuan untuk membahas mengenai prinsip Syariah prudential banking melalui early warning system (EWS) yang biasa bank syariah terapkan. Metode penelitian yang digunakan yakni kualitatif dengan pendekatan field research dan studi kepustakaan
\end{abstract}


dengan teknik pengumpulan data melalui observasi, wawancara dan dokumentasi. Hasil penelitian menyebutkan bahwa penerapan sistem pengukuran peringatan dini bagi bank syariah dapat dihitung menggunakan beberapa indikator, yakni meliputi return on equity (ROE), return on asset (ROA), financing to deposit ratio (FDR), non performing finaning (NPF) dan rasio biaya operasional dan pendapatan operasional (BOPO). Hal tersebut diterapkan dapat menekan tingkat pembiayaan bermasalah yang disebabkan oleh dua faktor, yakni faktor internal (pihak perbankan) adalah kurangnya maintenance yang telah ditetapkan, ketepatan dalam menganalisa usaha, pemahaman kebutuhan yang diperlukan, pencantuman persyaratan kebijakan yang sehat dan mengejar terget. Pada faktor eksternal (debitur) adalah bencana alam, usaha menurun, agunan, persaingan jenis usaha bertambah ketat, tingkat pendidikan yang rendah dan faktor keluarga.

Kata kunci: Analisis Pembiayaan, Sistem Peringatan Dini, Pembiayaan Bermasalah, Kesehatan Bank.

\section{A. PENDAHULUAN}

Dengan penduduk mayoritas muslim, perkembangan perbankan syariah seharusnya memiliki prospek yang sangat cerah. Apalagi perbankan syariah juga menganut prinsip universalitas, artinya memiliki prinsip yang juga dapat diperuntukkan bagi masyarakat luas atau pun semua kalangan. Keberadaan perbankan syariah dijadikan sebagai bagian dari sistem perbankan nasional yang diharapkan dapat mengembankan perekonomian Negara. ${ }^{1}$ Di masa pandemi, perbankan syariah di Indonesia menunjukkan tren perkembangan positif. Perbankan syariah tumbuh positif 9,22 persen (yoy) atau Rp 545,39 triliun. Perbankan syariah hingga bulan Maret 2020 terus menunjukkan perkembangan positif dengan Aset, Pembiayaan Yang Disalurkan dan Dana Pihak Ketiga yang terus tumbuh. Per Maret 2020, total aset keuangan syariah

${ }^{1}$ Ade Irvi Nurul Husna, “Arman Paramansyah, Perkembangan Industri Perbankan Syariah Pada Pembiayaan Yang Disalurkan", Jurnal Maps (Manajemen Perbankan Syariah), Vol. 3, No. 2, (2020), 129-139. 
Indonesia (tidak termasuk Saham Syariah) mencapai Rp1.497,44 triliun atau USD 91,49 miliar. $^{2}$

Tabel 1 Perkembangan Aset, PYD dan DPK

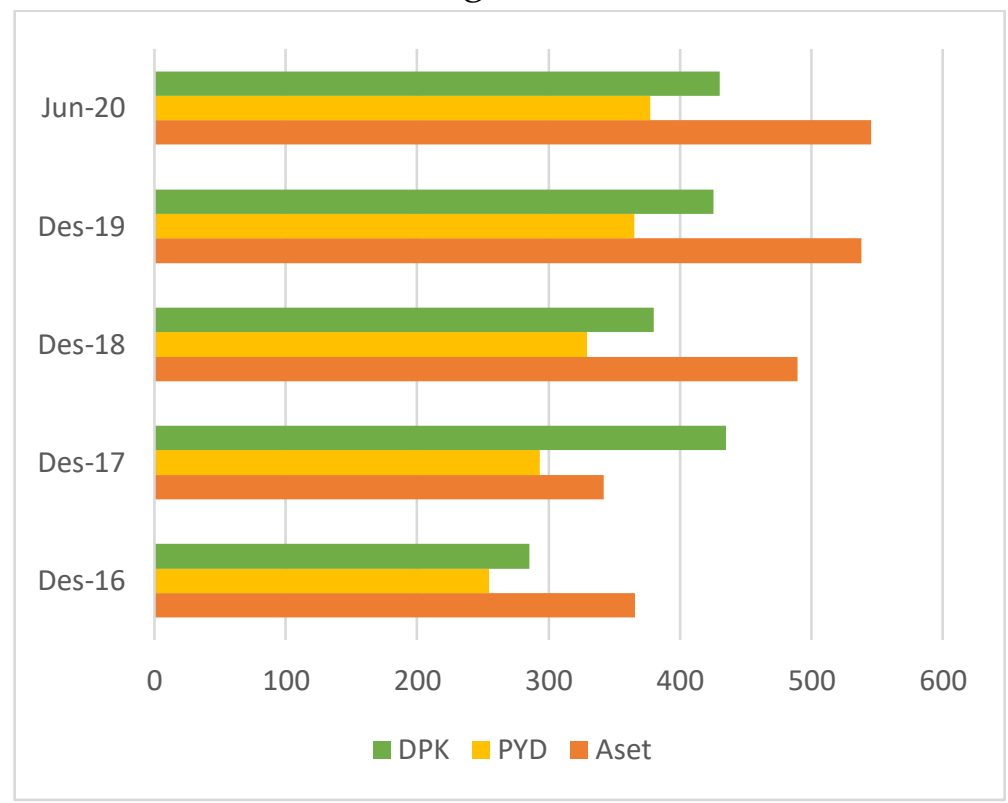

Sumber: Snapshot Perbankan Syariah - OJK

Menurut Pasal 36 bab 1, pasal 1, ayat 1 dalam Undang-Undang Republik Indonesia Nomor 21 Tahun 2008 tentang Perbankan Syariah. Perbankan Syariah adalah segala sesuatu yang menyangkut tentang Bank Syariah dan Unit Usaha Syariah mencakup kelembagaan, kegiatan usaha, serta cara dan proses dalam melaksanakan kegiatan usahanya. Bank Syariah adalah bank yang menjalankan kegiatan usahanya berdasarkan Prinsip Syariah. Prinsip Syariah adalah prinsip hukum Islam dalam kegiatan perbankan berdasarkan fatwa yang dikeluarkan oleh lembaga yang memiliki kewenangan dalam penetapan fatwa di bidang syariah. ${ }^{3}$

Perbankan syariah yang menjadi suatu lembaga keuangan syariah harus berpegang teguh pada prinsip syariah. Salah satu contohnya

2 Otoritas Jasa Keuangan (OJK), Snapshot Perbankan Syariah Juni 2020, https://ojk.go.id/id/kanal/syariah/berita-dan-kegiatan/publikasi/Pages/SnapshotPerbankan-Syariah-Juni-2020.aspx, diakses pada 29 September 2020.

3 Pasal 36 Undang-Undang Republik Indonesia Nomor 21 Tahun 2008 tentang Perbankan Syariah. 
dengan memberikan pelayanan yang lengkap, nyaman, dan diterima oleh masyarakat. Perbankan syariah memiliki berbagai macam produk baik pendanaan, pembiayaan dan jasa sebagai upaya untuk memenuhi kebutuhan masyarakat. Produk yang paling diminati dan dibutuhkan oleh masyarakat salah satunya adalah produk pembiayaan. Produk pembiayaan atau penyaluran dana merupakan istilah yang dipergunakan dalam perbankan syariah, dan istilah kredit dalam bank konvensional. ${ }^{4}$ Pembiayaan pada umumnya menjadi salah satu fungsi bank dalam menjalankan aktivitas penyaluran atau penggunaan dana. Arti sempitnya, pembiayaan didefinisikan sebagai penyaluran dana yang dilakukan lembaga keuangan syariah seperti pihak bank kepada nasabah. ${ }^{5}$ Pelaksanaan pembiayaan dalam perbankan syariah juga harus memenuhi aspek syariah dan aspek ekonomi. Setiap realisasi pembiayaan yang dijalankan pihak perbankan syariah kepada para debitur harus berpedoman pada syariat Islam dan tetap mempertimbangkan perolehan keuntungan atau bagi hasil baik bagi pihak perbankan syariah maupun nasabah. ${ }^{6}$

Besar kecilnya pembiayaan yang disalurkan oleh bank sangat dipengaruhi oleh banyak faktor. Faktor-faktor tersebut juga dapat menimbulkan salah satunya pembiayaan bermasalah. ${ }^{7}$ Faktor yang menyebabkan pembiayaan bermasalah terjadi yakni berasal dari pihak perbankan itu sendiri, seperti kesalahan analisa pembiayaan, kesalahan

4 Supriadi, Ismawati, "Implementasi Prinsip-prinsip Perbankan Syariah Untuk Mempertahankan Loyalitas Nasabah", Jurnal Hukum Ekonomi Syariah, Vol. 3, No. 1, April (2020), 41-50.

${ }^{5}$ M. Sulhan \& Ely Siswanto, Manajemen Bank Konvensional dan Syariah, (Malang: UIN Malang Press Cet; 1, 2008),148.

${ }^{6}$ Andi Sri Rezky W, Abd Basir, "Penerapan Prinsip Bagi Hasil Pada Pembiayaan di Bank Syariah Menurut Undang-Undang Perbankan Syariah", Khatulistiwa Law Review, Vol. 1 No. 1, April (2020), 61-76.

7 Wulandari Kuswahariani, et al, "Analisis Non Performing Financing (NPF) Secara Umum dan Segmen Mikro Pada Tiga Bank Syariah Nasional di Indonesia", Jurnal Aplikasi Bisnis dan Manajemen, Vol. 6, No. 1, Januari (2020), 26. 
dalam perhitungan modal dan jaminan serta kurang tepatnya penerapan sistem deteksi dini. Faktor lain bisa juga terjadi pada pihak debitur akan kecurangannya. Dengan begitu pemahaman yang baik atas faktor-faktor terjadinya pembiayaan bermasalah menjadi bekal yang sangat berharga bagi pihak perbankan yang bersangkutan. ${ }^{8}$ Untuk pembiayaan bermasalah atau bisa disebut dengan non performing financing (NPF) adalah pembiayaan yang memiliki beberapa macam golongan yakni kurang lancar, diragukan, dan macet. NPF mencerminkan risiko yang berkemungkinan pada kerugian yang akan timbul atas penyaluran dana oleh bank. Tingginya NPF membuat bank perlu membentuk pencadangan atas pembiayaan bermasalah yang lebih besar, karena hal ini akan menurunkan pendapatan bank. ${ }^{9}$

Tabel 2 Non Performing Financing (NPF)

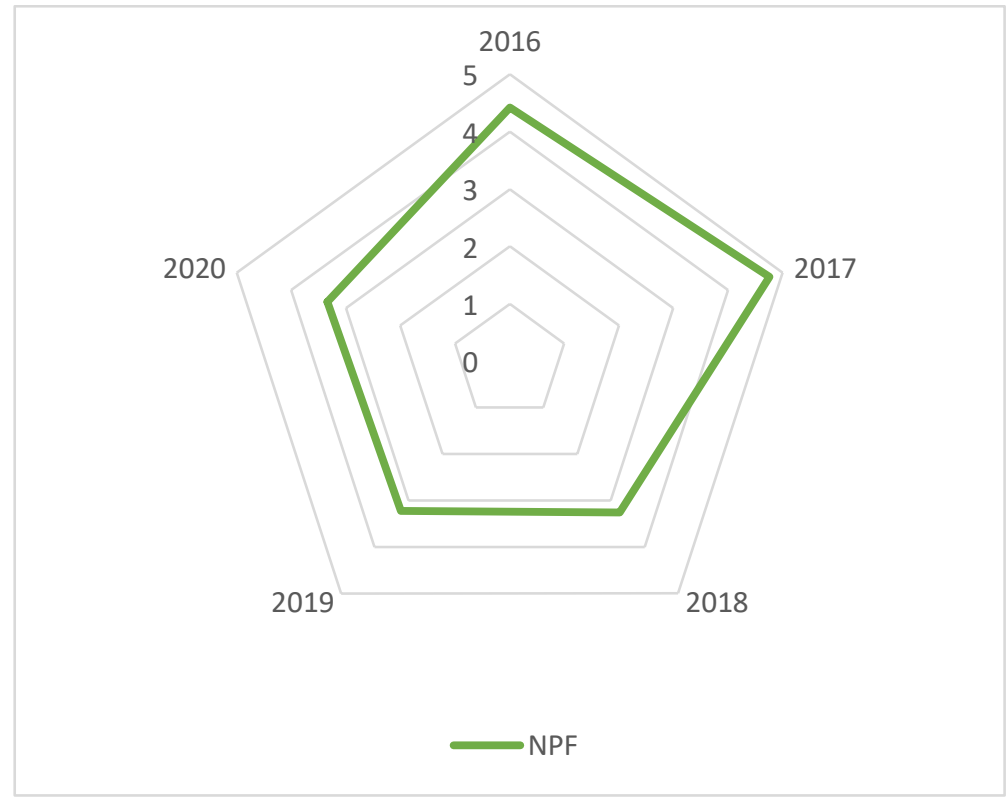

Sumber: Statistik Perbankan Syariah - OJK

8 Yulya A, Lukytawati A, Ranti W, "Faktor-Faktor yang Mempengaruhi Non Performing Financing Pada Bank Umum Syariah Indonesia Periode 2010-2014", Jurnal Al Muzara'ah, Vol. 4, No. 1, (2016), 44-60.

${ }^{9}$ Ismail Nawawi, Manajemen Perbankan dari Teori Menuju Aplikasi, (Jakarta: Kencana, 2010), 125. 
Tingkat pertumbuhan pembiayaan yang tinggi, diikuti dengan tingginya nilai FDR ternyata juga berdampak pada rasio NPF yang tinggi. Nilai NPF di akhir tahun 2020 perlu mendapat perhatian khusus karena dapat menimbulkan kerugian bagi bank syariah. Namun hal tersebut masih di bawah ambang batas NPF yang ditetapkan oleh Bank Indonesia yaitu sebesar $5 \% .{ }^{10}$ Kerugian yang dialami dapat mengganggu neraca bank, sehingga mengurangi kemampuan aktivanya. Jika kerugian tersebut cukup besar, maka bukan tidak mungkin bank akan mengalami likuidasi. Keberadaan NPF dalam jumlah besar dapat berdampak pada kerugian bank yaitu kerugian karena tidak diterimanya kembali dana yang telah disalurkan dan pendapatan tidak dapat diterima, artinya bank kehilangan kesempatan mendapat laba. Selain itu NPF juga berdampak pada berkurangnya pendapatan dari pembiayaan tersebut yang dapat mengurangi laba bank dan kemampuan memberikan pembiayaan. ${ }^{11}$

Faktor-faktor yang menyebabkan pembiayaan bermasalah atau non performing financing (NPF) dari perspektif bank dapat dilihat dari faktor internal dan faktor eksternal. Faktor internal bisa dilihat pada suatu kebijakan yang dijalankan oleh bank tersebut seperti kebijakan perkreditan yang ekspansif, penyimpangan dalam pelaksanaan prosedur perkreditan, lemahnya sistem administrasi dan pengawasan kredit, lemahnya sistem deteksi dini dan lemahnya informasi kredit, maupun itikad kurang baik dari pihak bank. ${ }^{12}$ Sedangkan faktor eksternal yang

10 Otoritas Jasa Keuangan (OJK), Statistik Perbankan Syariah Agustus 2020, https://www.ojk.go.id/id/kanal/syariah/data-dan-statistik/statistik-perbankansyariah/Pages/Statistik-Perbankan-Syariah---Agustus-2020.aspx, diakses pada 30 September 2020.

11 Fifi Hanafia, Abdul Karim, "Analisis CAR, BOP, NPF, FDR, NOM dan DPK Terhadap Profitabilitas (ROA) Pada Bank Syariah di Indonesia", Jurnal Manajemen dan Bisnis, Vol. 2 No. 1, (2020), 36-47.

12 Jaenal Effendi, Usy Thiarany, Tita Nurmansyah, "Factors Influencing NonPerforming Financing (NPF) at Sharia Banking", Jurnal Penelitian Sosial Keagamaan, Vol. 25 No. 1, (2017), 109-138. 
menyebabkan pembiayaan bermasalah atau non performing financing (NPF) bisa dilihat pada kegiatan usaha debitur yang menyebabkan pembiayaan bermasalah terjadi seperti penurunan kegiatan ekonomi dan tingginya suku bunga kredit, pemanfaatan iklim persaingan perbankan yang tidak sehat oleh debitur, kegagalan usaha debitur, maupun musibah yang dialami oleh debitur. ${ }^{13}$

Menurunnya pendapatan bank akan berpengaruh terhadap menurunnya modal yang dimiliki oleh bank. Karena besarnya modal yang dimiliki oleh bank akan berpengaruh pada besarnya ekspansi dalam menyalurkan dana dalam pembiayaan. Sehingga peningkatan modal bisa diketahui dari tingkat NPFnya, yakni semakin tinggi nilai NPF akan semakin tinggi tingkat kerugian yang dialami lembaga keuangan syariah. Dan juga sebaliknya, semakin kecil tingkat NPF maka tingkat keuntungan lembaga keuangan syariah akan meningkat. ${ }^{14}$ Menurut Pasal 25, bab 6, ayat 1 dan 2 dalam Undang-Undang Republik Indonesia Nomor 23 Tahun 1999 tentang Bank Indonesia bahwa dalam rangka melaksanakan tugas mengatur bank, Bank Indonesia berwenang menetapkan ketentuanketentuan perbankan yang memuat prinsip kehati-hatian dan sistem deteksi dini. Pelaksanaan kewenangan sebagaimana dimaksud pada ayat 1 ditetapkan dengan Peraturan Bank Indonesia. ${ }^{15}$ Sehingga pihak bank harus menerapkan prinsip kehati-hatian (prudential banking) yang dijadikan acuan melalui mekanisme atau sistem deteksi dini (early warning system) yang dijadikan sebagai pengenalan terhadap tanda-tanda atau gejala awal yang diperkirakan dapat mempengaruhi perkembangan atas maju mundurnya keuangan dan operasi perbankan.

\footnotetext{
13 Siamat, Dahlan, Manajemen Lembaga Keuangan: Kebijakan Moneter dan Perbankan Edisi Kelima, (Jakarta: Lembaga Penerbit Fakultas Ekonomi Universitas Indonesia, 2005), 360.

${ }^{14}$ A. Wangsawidjaja Z, Pembiayaan Bank Syariah, (Jakarta: Gramdeia Pustaka, 2012$), 76$.

${ }_{15}$ Pasal 25 Undang-Undang Republik Indonesia Nomor 23 Tahun 1999 tentang Bank Indonesia.
} 
Sebagai lembaga keuangan syariah yang berbisnis dibidang ekonomi, tentunya pihak bank tidak ingin mengalami risiko kerugian sebagaimana halnya lembaga keuangan syariah lainnya. Oleh karena itu, bank syariah tidak serta merta memberikan kucuran dana kepada calon nasabah/debitur. ${ }^{16}$ Karena selain mengemban amanah dari pihak ketiga, bank syariah juga menerapkan prinsip prudential banking untuk menjaga dana yang diamanahkan melalui mekanisme early warning system untuk meminimalisir terjadinya tingkat non performing financing dan meningkatkan kesehatan bank. Kesehatan bank merupakan kepentingan semua pihak yang terkait, baik pemilik, manajemen, masyarakat pengguna jasa bank dan pemerintah dalam hal ini Bank Indonesia selaku otoritas pengawasan perbankan, karena kegagalan dalam industri perbankan akan berdampak buruk terhadap perekonomian Indonesia. ${ }^{17}$

Prinsip prudential banking adalah suatu asas atau prinsip yang menyatakan bahwa dalam menjalankan fungsi dan kegiatan usaha perbankan wajib bersikap hati-hati. ${ }^{18}$ Bank dalam memberikan pembiayaan harus melaksanaan prinsip kehati-hatian secara faktual dapat dilihat dalam penerapan mekanisme early warning system (EWS) yakni sebuah sistem yang dapat memberikan peringatan dini terhadap kemungkinan kesulitan keuangan dan operasi perbankan dimasa yang akan datang. Sistem pengukuran peringatan dini bagi bank syariah dapat dihitung menggunakan beberapa indikator, yakni meliputi return on equity, return on asset, financing to deposit ratio, non performing finaning dan rasio biaya operasional dan pendapatan operasional yang memang

16 Rahmat Ilyas, "Analisis Kelayakan Pembiayaan Bank Syariah", Jurnal AsySyar'iyyah: Jurnal Ilmu Syari'ah dan Perbankan Islam, Vol. 4, No. 2, Desember (2019), 124-146.

17 Diana Marlyna, Mohan Aka Wirando, "Analisa Tingkat Kesehatan Bank Syariah", Technobiz : International Journal Of Business, Vol. 1, No. 1, (2018), 19-24.

18 Sutan Remy, Perbankan Islam (Dalam Kedudukan Tata Hukum Di Indonesia), (Jakarta: Utama Puataka Grafikia, 2003), 172. 
dikhususkan untuk menghitung laporan keuangan perbankan. ${ }^{19}$ Dengan EWS diharapkan dapat mengantisipasi kemungkinan kegagalan dari berbagai kondisi pasar yang dinamis pada perbankan syariah. Sehingga, pembuat kebijakan dapat menyiapkan berbagai kebijakan untuk mengurangi dampak instabilitas perekonomian.

Kebijakan perbankan tersebut dikeluarkan dan dilaksanakan oleh Bank Indonesia untuk menciptakan kinerja yang baik dan memelihara kesehatan bank di Indonesia. Berikut ini adalah ayat yang berkaitan dengan kinerja dalam firman Allah Swt pada al-Qur'an surah at-Taubah (9) ayat 105:

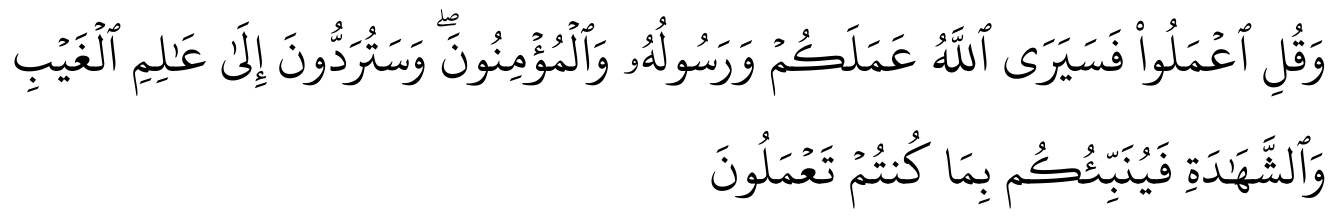

"Dan katakanlah: Bekerjalah kamu, Maka Allah dan Rasul-Nya serta orangorang mukmin akan melihat pekerjaanmu itu, dan kamu akan dikembalikan kepada (Allah) Yang Mengetahui akan yang gaib dan yang nyata, lalu diberitakan-Nya kepada kamu apa yang telah kamu kerjakan."20

Berdasarkan latar belakang masalah diatas, penulis tertarik untuk mengadakan penelitian dengan memahami, mengkaji, dan menganalisis tentang bagaimana penerapan prinsip kehati-hatian bank (prudential banking) melalui mekanisme sistem peringatan dini (early warning system) sebagai upaya penyelesaian yang digunakan bank syariah dalam menekan tingkat non performing financing dan faktor-faktor yang menyebabkan pembiayaan bermasalah muncul pada bank syariah.

19 Sumandi, "Analysis an Early Warning System on Sharia Banking Crisis", Jurnal Nisbah, Vol. 3 No. 1, (2017), 365-382.

${ }^{20}$ Departemen Agama RI, Al-Qur'an dan Terjemahannya, (Bandung: CV. Diponegoro, 2005), 162. 


\section{B. METODE PENELITIAN}

Metode penelitian yang digunakan yakni kualitatif dengan pendekatan studi kepustakaan serta field research dengan menggunakan latar belakang alamiah yang menghasilkan hasil penelitian secara deskriptif atau analisis dan juga memaparkan serta menggambarkan apa yang seseorang terima, rasakan dan ketahui didalam kesadaran langsungnya serta pengalamannya yang disesuaikan dengan konsep teoritis. ${ }^{21}$ Untuk mencapai tujuan penelitian, pada teknik pengumpulan data penulis mengumpulkan data melalui observasi, wawancara dan dokumentasi serta kajian dalam bentuk analisis dan olahan pengetahuan secara langsung mengenai penelitian terkait. Sedang analisis data bersifat deskriptif, karena penelitian ini akan menguraikan secara objektif hal-hal yang berkaitan dengan implementasi early warning system (EWS) dalam menekan tingkat non performing financing (NPF) di perbankan syariah.

\section{PEMBIAYAAN}

\section{Pengertian Pembiayaan}

Pembiayaan merupakan salah satu produk bank syariah dalam menyalurkan dana kepada calon nasabah atau calon debitur berdasarkan prinsip syariah. Penyaluran dana dalam bentuk pembiayaan didasarkan atas kepercayaan yang diberikan oleh pemilik dana kepada pengguna dana. Pemilik dana memberikan keopercayaan kepada penerima dana, bahwa dana dalam bentuk pembiayaan yang diberikan pasti akan terbayar atau kembali. Penerima dana pembiayaan mendapat kepercayaan dari pemilik dana, sehingga penerima pembiayaan berkewajiban untuk mengembalikan dana atas pembiayaan yang telah diterima sesuai dengan jangka waktu yang

${ }^{21}$ Suharsimi Arikunto, Prosedur Penelitian; Suatu Pendekatan Praktik, (Jakarta: Rhineka Cipta, 2010), 3. 
telah diperjanjikan dalam akad pembiayaan. ${ }^{22}$ Secara sederhana yang menjadi perbedaan antara kredit yang diberikan oleh bank konvensional dengan pembiayaan yang diberikan oleh bank syariah terletak pada keuntungan atau bagi hasil yang diharapkan. Pada bank konvensional, keuntungan diperoleh melalui bunga yang telah ditetapkan. Sedangkan pada bank syariah, berupa imbalan atau bagi hasil yang didapat. Perbedaan lain salah satunya terdiri dari analisis pemberian pembiayaan beserta persyaratannya. ${ }^{23}$

\section{Tujuan Pembiayaan}

Suatu bank dalam memberikan pembiayaan kepada calon nasabah atau calon debitur pastinya memiliki tujuan dengan tak lepas dari misi bank tersebut, tujuannya dibedakan menjadi dua yakni tujuan pembiayaan untuk tingkat makro dan mikro. Secara makro dijelaskan bahwa pembiayaan bertujuan sebagai berikut: ${ }^{24}$

a. Peningkatan ekonomi, yaitu dengan adanya pembiayaan masyarakat dapat melakukan akses ekonomi seperti kegiatan usaha dalam memenuhi kebutuhan hidup.

b. Tersedianya dana bagi peningkatan usaha, yaitu pihak bank yang mempunyai dana dapat menyalurkan dana kepada pihak yang membutuhkan dana sebagai modal usaha.

c. Meningkatkan produktifitas, yaitu memberikan peluang bagi masyarakat agar mampu meningkatkan daya produksinya dalam berusaha.

22 Ismail Nawawi, Perbankan Syariah, (Jakarta: Kencana, 2011), 105. 2010), 93

${ }^{23}$ Veithzal Rivai, Andria Permata, Islamic Financial Management, (Jakarta: Kencana,

24 Binti Nur Aisyah, Manajemen Pembiayaan Bank Syariah, (Yogyakarta: Kalimedia, 2015), 4 . 
d. Membuka lapangan kerja baru, yaitu dengan terbukanya sektorsektor usaha melalui dana pembiayaan, maka sektor usaha tersebut akan menyerap tenaga kerja atau pengangguran.

e. Terjadinya distribusi pendapatan, yaitu masyarakat yang berusaha produktif mampu melakukan aktivitas kerja dengan memperoleh pendapatan dari hasil usahanya.

Adapun secara mikro, tujuan pembiayaan adalah sebagai berikut: ${ }^{25}$

a. Upaya memaksimalkan laba, yaitu setiap usaha akan menghasilkan laba usaha yang dimaksimalkan untuk perolehan kembalinya dana yang telah dikeluarkan.

b. Upaya meminimalkan risiko, yaitu setiap usaha pasti akan terjadi faktor-faktor yang berpengaruh maka pengusaha harus mampu meminimalkan risiko yang mungkin timbul.

c. Pemberdayaan sumber ekonomi, yaitu sumber daya ekonomi dapat dikembangkan dengan melakukan mixing antara sumber daya alam dengan sumber daya manusia serta sumber daya modal yang diperoleh.

d. Penyaluran kelebihan dana, yaitu pembiayaan dapat menjadi penyeimbangan dan penyaluran kelebihan dana dari pihak yang kelebihan dana kepada pihak yang kekurangan dana.

\section{Kategori Pembiayaan}

Penggolongan kolektabilitas pembiayaan menurut pasal 4 surat keputusan direktur Bank Indonesia No. 30/267/KEP/DIR tanggal 27 Februari 1998, yaitu sebagai berikut:26

a) Lancar (pass), apabila memnuhi kriteria:

1) Pembayaran angsuran pokok dan bunga tepat

${ }^{25}$ Ibid., 5 .

${ }^{26}$ Iswi Hariyani, Restruturisasi dan Penghapusan Kredit Macet, (Jakarta: PT Elex Media Komputindo, 2010), 37. 
2) Memiliki mutase rekening yang aktif

3) Bagian dari kredit yang dijamin dengan agunan tunai (cash collateral)

b) Dalam perhatian khusus (special mention), apabila memenuhi kriteria:

1) Terdapat tunggakan angsuran pokok belum melampaui 90 hari

2) Terkadang terjadi cerukan (overdraft)

3) Mutasi rekening rendah

4) Jarang terjadi pelanggaran terhadap kontrak yang diperjanjikan

5) Didukung oleh pinjaman baru

c) Kurang lancar (substandard), apabila memenuhi kriteria:

1) Terdapat tunggakan angsuran pokok dan bunga yang telah melampaui 90 hari

2) Sering terjadi cerukan (overdraft)

3) Frekuensi mutase rekening relatif rendah

4) Terjadi pelanggaran terhadap kontrak yang diperjanjikan lebih dari 90 hari

5) Terdapat indikasi masalah keuangan yang dihadapi debitur

d) Diragukan (doubtfull), apabila memenuhi kriteria:

1) Terdapat tunggakan angsuran pokok dan bunga yang telah melampaui 180 hari

2) Terjadi cerukan (overdraft) yang bersifat permanen

3) Terjadi wanprestasi lebih dari 180 hari

4) Terjadi kapitalisasi bunga

5) Dokumentasi hukum yang lemah baik untuk perjanjian kredit maupun pengikatan jaminan

e) Macet (loss), apabila memenuhi kriteria: 
1) Terdapat tunggakan angsuran pokok dan bunga yang telah melampaui 270 hari

2) Kerugian operasional ditutup dengan pinjaman baru

3) Dari segi hukum maupun kondisi pasar, jaminan tidak dapat dicairkan pada nilai wajar

Dalam perbankan syariah pembiayaan yang bermasalah dikenal dengan sebutan Non Performing Financing (NPF), dan Non Performing Loan (NPL) pada bank konvensional. ${ }^{27}$ Hal tersebut menggambarkan situasi dimana pengembalian pembiayaan yang telah diberikan mengalami risiko yang tidak diinginkan. Dalam pengartian lain Non Performing Financing (NPF) dapat dipahami bahwa pembiayaan yang kualitas pembayarannya sudah turun dari lancar, kurang lancar, dalam perhatian khusus, diragukan dan macet. Pembiayaan yang dalam pengembaliannya mengalami keterlambatan baik pokoknya maupun bagi hasil..28 Pembiayaan bermasalah atau Non Performing Financing (NPF) adalah suatu rasio yang membandingkan tingkat pembiayaan bermasalah atau pembiayaan yang dikualifikasikan terhadap total pembiayaan yang diberikan. Perhitungannya Non Performing Financing (NPF) yakni perbandingan antara pembiayaan yang memiliki kualitas kurang lancar, diragukan dan macet dibandingkan dengan total pembiayaan yang disalurkan. ${ }^{29}$ Besarnya rasio Non Performing Financing (NPF) yang diperbolehkan Bank Indonesia adalah maksimal 5\%, jika melebihi angka 5\% maka akan mempengaruhi penilaian tingkat kesehatan bank yang bersangkutan. ${ }^{30}$

${ }^{27}$ Fatwa Dewan Syariah Nasional No. 07/DSN-MUI/IV/2000 tentang Pembiayaan.

${ }^{28}$ Rahmat Shaleh, Kamus Perbankan, (Jakarta: Institut Perbankan Indonesia, 1980), 142.

${ }^{29}$ Katiyo, Analisa Kredit dan Resiko, (Jakarta: Institut Bankir Indonesia, 2004), 67.

30 Trisadini P. Usanti, Transaksi Bank Syariah, cet. 1, (Jakarta: Bumi Aksara, 2013), 105. 


\section{EARLY WARNING SYSTEM}

Dalam menerapkan prinsip kehati-hatian, bank menganalisis atau menilai permohonan pembiayaan dibahas melalui berbagai aspek yang menyangkut keadaan usaha calon debitur. ${ }^{31}$ Untuk meminimalisir dan mencegah terjadinya kerugian akibat pembiayaan yang bermasalah, maka bank harus menerapkan suatu sistem yang efektif dan berkesinambungan untuk memonitoring fasilitas pembiayaan yang telah diberikan melalui early warning system (EWS). Indikator yang digunakan untuk mencari periode tekanan merupakan hasil indeksasi dari lima indikator, yaitu return on equity, return on asset, financing-to-asset ratio, non performing finaning dan rasio biaya operasional dan pendapatan operasional yang memang dikhususkan untuk menghitung laporan keuangan perbankan. ${ }^{32}$

\section{Return on Equity (RoE) $)^{33}$}

ROE adalah rasio yang digunakan untuk mengukur pendapatan (laba) dari penggunaan modal bank syariah. Dapat dirumuskan dengan,

$$
R O E=\frac{\text { Laba Bersih }}{\text { Modal Sendiri }} \times 100 \%
$$

\section{Return on Asset (RoA)}

ROA aadalah rasio yang digunakan untuk mengukur kemampuan manajemen bank syariah dalam memperoleh pendapatan dari total penggunaan asset bank syariah. Dapat dirumuskan dengan,

$$
R O A=\frac{\text { Laba Bersih }}{\text { Total Aset }} \times 100 \%
$$

\section{Financing-to-Asset Ratio (FAR)}

\footnotetext{
${ }^{31}$ Kasmir, Dasar-dasar Perbankan (Edisi Revisi), (Jakarta: Rajawali Pers, 2013), 95.

32 Sumandi, Analysis an Early Warning System, ..., 365-382.

33 Sunarto Zulkifli, Panduan Praktis Transaksi Perbankan Syariah, (Jakarta: Ziktul Hakim,
} 2007), 144. 
FAR adalah nisbah keuangan yang menilai kemampuan bank dalam memenuhi kewajiban jangka pendeknya dan permohonan kredit atau pembiayaan dengan cepat. Dapat dirumuskan dengan,

$$
F A R=\frac{\text { Total Pembiayaan }}{\text { Total Aset }} \times 100 \%
$$

\section{Non Performing Financing (NPF)}

NPF dapat dipahami bahwa pembiayaan yang kualitas pembayarannya sudah turun dari lancar, kurang lancar, dalam perhatian khusus, diragukan dan macet. Pembiayaan yang dalam pengembaliannya mengalami keterlambatan baik pokoknya maupun bagi hasil. ${ }^{34}$ Dapat dirumuskan dengan,

$$
N P F=\frac{(\text { Pembiayaan }}{\text { (Kurang Lancar, Diragukan, Macet) }} \times 100 \%
$$

\section{Rasio Biaya Operasional dan Pendapatan Operasional (BOPO)}

BOPO merupakan salah satu rasio biaya yang menunjukkan sejauh mana nilai efesiensi kinerja operasional bank syariah. Nilai BOPO menurun apabila biaya operasional menurun di lain pihak pendapatan operasional tetap dan apabila biaya operasional tetap di lain pihak pendapatan operasional meningkat. Dapat dirumuskan dengan,

$$
B O P O=\frac{\text { Biaya Operasional }}{\text { Pendapatan Operasional }} \times 100 \%
$$

\section{E. IMPLEMENTASI EARLY WARNING SYSTEM (EWS) DALAM MENEKAN TINGKAT NON PERFORMING FINANCING (NPF)}

Sebagaimana telah dideskripsikan pada sub bab sebelumnya, bahwa setiap pembiayaan yang diberikan oleh pihak bank kepada calon debitur harus menerapkan prinsip prudential banking. Menurut Rachmadi Usman, prinsip prudential banking adalah suatu sikap kehati-hatian pihak

${ }^{34}$ Rahmat Shaleh, Kamus Perbankan, ..., 142. 
bank dalam menjalankan tugas atau kinerjanya dalam melayani nasabah. ${ }^{35}$ Didalam prinsip prudential banking terdapat cara dalam menilai atau menganalisa calon debitur dalam permohonan pembiayaan yang diajukan. Hal ini diterapkan dengan tujuan untuk menekan tingkat non performing financing dan meningkatkan kesehatan bank. Dengan meminimalisir terjadinya risiko yang tidak diharapkan, pihak bank dari awal memiliki tahap atau cara tersendiri dalam menilai maksud dan tujuan calon debitur. Hal pertama yang dilakukan $\mathrm{AO}$ adalah persiapan pemberian pembiayaan. Persiapan pemberian pembiayaan merupakan tahap pertama dalam pemberian pembiayaan kepada calon debitur. Dalam tahap ini AO selaku pihak bank harus menggali informasi mengenai data pribadi calon debitur. Informasi yang diambil harus memiliki gambaran mengenai kondisi suatu usaha calon debitur yang menyangkut besarnya usaha, besarnya pembiayaan yang diminta, tujuan digunakannya modal pembiayaan, jaminan, dan lokasi usaha. AO juga menginformasikan kepada calon debitur mengenai kebijakan pembiayaan yang ada di bank syariah. ${ }^{36}$

Sebelum persetujuan akad dengan pemberian seluruh berkas yang telah disetujui pihak bank seperti tata cara pengajuan pembiayaan, syaratsyarat permohonan pembiayaan dan yang lainnya. Dari data-data yang telah dikumpulkan, baik dari hasil wawancara, tertulis, intern bank, kemudian diolah dalam laporan pengenalan proyek. Kemudian AO memberikan formulir, sehingga calon debitur akan memberikan data mengenai surat-surat berkaitan dengan pembiayaan, jaminan dan

\footnotetext{
${ }^{35}$ Rachmadi Usman, Aspek-aspek Hukum Perbankan di Indonesia, (Jakarta: PT: Gramedia Pustaka Utama, 2001), 18.

36 Mardiana Yose, Rully Trihantana, "Participation and Financing Mechanism Islamic Bank on Syndication", Jurnal Nisbah, Vol. 3, No. 2, (2017), 403-423.
} 
dokumen pendukung lainnya. ${ }^{37}$ Selanjutnya $\mathrm{AO}$ menilai melalui dokumentasi dengan mengecek data-data dokumen yang telah diserahkan dan memproses pada tahap berikutnya. Sebelum pencairan dana nantinya juga harus memberikan surat permohonan realisasi pembiayaan dan dokumen tambahan yang disyaratkan. Tahap berikutnya masuk pada analisis pembiayaan.

Setelah menganalisa pembiayaan yang diajukan oleh calon debitur, berikutnya AO melaporkan kepada komite pembiayaan untuk memperoleh keputusan. Menurut Sunarto Zulkifli jika tidak sesuai maka persyaratan akan dikembalikan ke calon debitur dan account officer menyampaikan penolakkannya. Bila permohonan pembiayaan disetujui atau dianggap layak serta memenuhi kriteria, maka komite akan memberikan persetujuan sesuai dengan persyaratan yang diberikan. ${ }^{38}$ Kemudian AO melakukan pengecekan ulang berkas-berkas yang telah terkumpul apakah sudah lengkap dan sesuai prosedur atau belum. Setelah semua terlengkapi, maka data akan diinput ke sistem dan dana akan dicairkan kepada debitur.

Untuk meminimalisir dan mencegah terjadinya kerugian akibat pembiayaan yang sudah dicairkan kepada debitur, maka bank harus menerapkan suatu sistem yang efektif dan berkesinambungan untuk memonitoring fasilitas pembiayaan yang telah diberikan melalui early warning system (EWS). Early warning system (EWS) yakni sebuah sistem yang dapat memberikan peringatan dini terhadap kemungkinan kesulitan keuangan dan operasi perbankan dimasa yang akan datang. Sistem pengukuran peringatan dini bagi bank syariah dapat dihitung menggunakan beberapa indikator, yakni meliputi return on equity, return

\footnotetext{
37 Muhammad Syafi'i Antonio, Bank Syariah Bagi Bankir dan Praktisi Keuangan, (Jakarta: Gema Insani dan Tazkia, 1999), 160.

38 Sunarto Zulkifli, Panduan Praktis ..., 144.
} 
on asset, financing to desposit ratio, non performing finaning dan rasio biaya operasional dan pendapatan operasional yang memang dikhususkan untuk menghitung laporan keuangan perbankan. ${ }^{39}$ Sebagai contoh laporan keuangan tahunan di salah satu bank syariah di Indonesia yakni Bank Syariah Bukopin misalnya,

Tabel 3 Laporan Tahunan

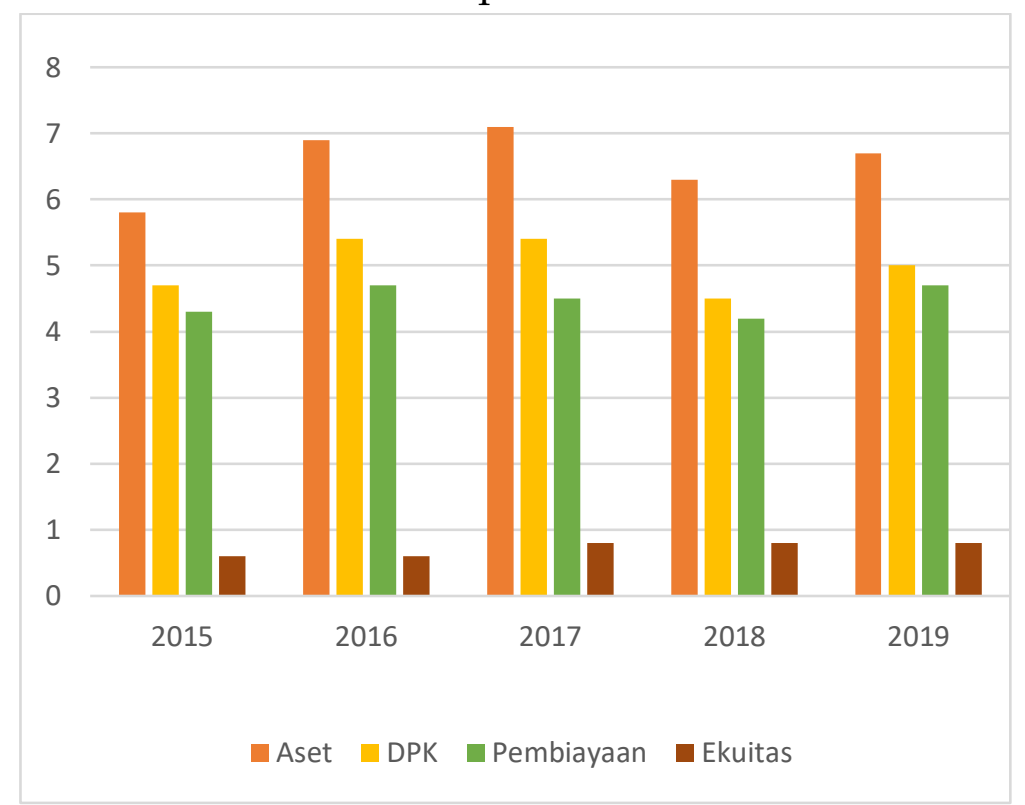

Sumber: Laporan Keuangan Tahunan - BSB

Tabel 4 Rasio Keuangan

\begin{tabular}{|l|r|r|r|r|r|}
\hline Description & \multicolumn{1}{|c|}{2015} & \multicolumn{1}{c|}{2016} & \multicolumn{1}{c|}{2017} & \multicolumn{1}{c|}{2018} & \multicolumn{1}{c|}{2019} \\
\hline $\begin{array}{l}\text { Capital Adequacy Ratio } \\
\text { (CAR) }\end{array}$ & 16,31 & 15,15 & 19,20 & 19,31 & 15,25 \\
\hline $\begin{array}{l}\text { Non performing earning } \\
\text { assets and non total } \\
\text { performing non earning } \\
\text { assetss to total earning } \\
\text { assets and non earning } \\
\text { assets }\end{array}$ & 2,44 & 5,64 & 5,33 & 4,50 & 6,54 \\
\hline $\begin{array}{l}\text { Non performing assets to } \\
\text { total earning assets }\end{array}$ & 2,44 & 5,71 & 5,48 & 4,42 & 4,60 \\
\hline $\begin{array}{l}\text { Allowance for impairment } \\
\text { losses on financial assets to } \\
\text { earning assets }\end{array}$ & 1,36 & 3,38 & 3,94 & 4,18 & 4,08 \\
\hline
\end{tabular}

39 Sumandi, Analysis an Early Warning System, ..., 365-382. 


\begin{tabular}{|l|r|r|r|r|r|}
\hline $\begin{array}{l}\text { Non Performing Financing } \\
\text { (NPF) Gross }\end{array}$ & 2,99 & 7,63 & 7,85 & 5,71 & 5,89 \\
\hline $\begin{array}{l}\text { Non Performing Financing } \\
\text { (NPF) Net }\end{array}$ & 2,74 & 4,66 & 4,18 & 3,65 & 4,05 \\
\hline Return on Asset (ROA) & 0,79 & $(1,12)$ & 0,02 & 0,02 & 0,04 \\
\hline Return on Equity (ROE) & 5,35 & $(13,74)$ & 0,20 & 0,26 & 0,23 \\
\hline Net Return & 3,14 & 3,31 & 2,44 & 3,17 & 2,59 \\
\hline Net Operating Margin & 0,27 & $(1,67)$ & $(0,40)$ & $(0,38)$ & $(0,29)$ \\
\hline $\begin{array}{l}\text { Operating Ecpense to } \\
\text { Operating Income (BOPO) }\end{array}$ & 91,99 & 109,62 & 99,20 & 99,45 & 99,60 \\
\hline $\begin{array}{l}\text { Financing to Deposit Ratio } \\
\text { (FDR) }\end{array}$ & 90,56 & 88,18 & 82,44 & 93,40 & 93,48 \\
\hline Quick Ratio & 16,19 & 23,75 & 26,60 & 20,31 & 18,44 \\
\hline $\begin{array}{l}\text { Profit Sharing Share to } \\
\text { Total Financing }\end{array}$ & 48,09 & 52,56 & 60,71 & 63,59 & 65,15 \\
\hline
\end{tabular}

Sumber: Laporan Keuangan tahunan - BSB

Ditinjau dari perhitungan return on equity (ROE) menunjukkan satuan angka 0,23 ditahun 2019 mendekati 1 menunjukkan semakin efektif dan efisiennya penggunaan ekuitas perusahaan untuk menghasilkan pendapatan, demikian sebaliknya jika ROE mendekati 0 berarti perbankan tidak mampu mengelola modal yang tersedia secara efisien untuk menghasilkan pendapatan. ${ }^{40}$ ROE atau yang biasa disebut pengembalian ekuitas adalah salah satu perhitungan yang masuk dalam rasio profitabilitas. ROE merupakan perhitungan rasio yang menunjukkan kemampuan perbankan dalam menghasilkan laba bersih dengan menggunakan modal sendiri dan menghasilkan laba bersih yang tersedia bagi pemilik atau investor. Rasio ini menunjukkan daya untuk menghasilkan laba atas investasi berdasarkan nilai buku para pemegang saham, dan sering kali digunakan dalam membandingkan dua atau lebih perusahaan atas peluang investasi yang baik dan manajemen biaya yang efektif. ROE sangat menarik bagi pemegang maupun calon pemegang

40 Bank Syariah Bukopin, Laporan Keuangan Tahunan 2019, https://www.syariahbukopin.co.id/id/laporan/2019, diakses pada tanggal 16 November 2020. 
saham, dan juga bagi manajemen, karena rasio tersebut merupakan ukuran atau indikator penting dari shareholders value creation, artinya semakin tinggi rasio ROE, semakin tinggi pula nilai perusahaan, hal ini tentunya merupakan daya tarik bagi investor untuk menanamkan modalnya di perusahaan tersebut. ${ }^{41}$

Selanjutnya yakni return on assets untuk mengukur efisiensi dalam mengubah uang yang digunakan untuk membeli aset menjadi laba bersih. Perbankan juga perlu memahami return on assets (ROA) secara keseluruhan untuk tolak ukuran keuntungan yang paling tepat. ROA merupakan rasio yang menunjukan hasil (return) atas jumlah aktiva yang digunakan dalam perusahaan. Rasio ini juga merupakan suatu ukuran tentang efektivitas manajemen dalam mengelola investasinya. Semakin kecil (rendah) rasio dari ROA, maka semakin kurang baik demikian pula sebaliknya. Dapat dilihat perhitungan dari ROA menunjukkan satuan angka 0,04 atau setara dengan 4\% di tahun terakhir 2019.42 Dengan demikian, bisa dimengerti bahwa return on assets menunjukkan hasil yang lebih tinggi bahwa perusahaan tersebut lebih efektif dalam mengelola asetnya dan lebih produktif dalam menghasilkan jumlah laba bersih yang lebih besar. Idealnya semakin tinggi angka ROA, maka akan semakin baik asumsi kinerja perusahaan tersebut dari sisi pengelolaan ekuitasnya. Namun, untuk mengetahui nilai ROA yang baik tidak ada standar khusus.

Kemudian adanya perhitungan pada financing-to-deposit ratio (FDR) yang menunjukkan peningkatan di tiap tahunnya. Semakin tinggi financing to deposit ratio atau FAR maka tingkat likuiditasnya rendah karena jumlah aset yang diperlukan untuk membiayai pembiayaannya makin besar. Besarnya jumlah pembiayaan yang disalurkan akan

\footnotetext{
${ }^{41}$ Muhammad Ash-Shiddiqy, "An Analysis Of Profitability Of Sharia Banks Using Return On Asset (ROA) Ratio And Return On Equity (ROE) Ratio", Jurnal Imara, Vol. 3, No. 2, Desember (2019), 117-129.

42 Bank Syariah Bukopin, Laporan Keuangan Tahunan 2019, ..., 16 November 2020.
} 
menentukan laba bank syariah. Jika bank tidak mampu menyalurkan pembiayaan sementara dana yang terhimpun banyak maka akan menyebabkan bank tersebut merugi. Semakin besar pembiayaan yang disalurkan dibandingkan dengan simpanan pada suatu bank membawa konsekuensi semakin besar risiko yang harus ditanggung oleh bank yang bersangkutan. ${ }^{43}$ Sehingga akan menyebabkan semakin besar pula kemungkinan terjadinya pembiayaan bermasalah. Pembiayaan bermasalah di bank syariah biasa disebut non performing financing (NPF), dimana suatu gambaran situasi, dimana persetujuan pengembalian pinjaman mengalami risiko kegagalan, bahkan cenderung menuju/mengalami rugi yang potensial (potential loss). ${ }^{44}$

Besarnya rasio NPF yang diperbolehkan Bank Indonesia adalah maksimal 5\%, jika melebihi angka 5\% maka akan mempengaruhi penilaian tingkat kesehatan bank yang bersangkutan. ${ }^{45}$ Dalam perhitungan rasio NPF menunjukkan 4,05\% dimana kategori tersebut memasuki peringkat 2 dengan keterangan sehat. Namun harus tetap siaga karena akan mendekati batas maksimum yang sudah ditetapkan oleh Bank Indonesia. Penilaian rasio terakhir adalah biaya operasional dan pendapatan operasional (BOPO), dimana rasio yang menggambarkan efisiensi perbankan dalam melakukan kegiatannya. Belanja operasional adalah biaya bagi hasil yang diberikan pada nasabah sedangkan pendapatan operasional adalah bagi hasil yang didapatkan dari nasabah. Semakin kecil nilai BOPO artinya semakin efisien perbankan dalam

43 Supriono, "Analisis Pengaruh Financing To Deposit Ratio (FDR) Terhadap Penempatan Dana Pada Sbis Bank Syariah Di Indonesia", Jurnal Ekonomi Syariah Teori dan Terapan, Vol. 4, No. 7, Juli (2017), 531-546.

${ }^{44}$ Rahmat Shaleh, Kamus Perbankan, ..., 142.

${ }^{45}$ Fatwa Dewan Syariah Nasional No. 07/DSN-MUI/IV/2000 tentang Pembiayaan. 
beroperasi. ${ }^{46}$ Terlihat perhitungan BOPO mengalami fluktuasi dengan naik turunnya rasio yang tercantum dari tahun 2015-2019.47 Hal tersebut membutuhkan strategi yang eksklusif guna efisiensi dalam mengeluarkan biaya dalam rangka menghasilkan pendapatan yang lebih tinggi.

\section{F. FAKTOR-FAKTOR YANG MENYEBABKAN NPF (NON PERFORMING FINANCING) MUNCUL}

Menurut Kasmir, faktor-faktor yang menyebabkan terjadinya pembiayaan bermasalah di bank syariah diketahui melalui dua faktor, yakni faktor internal dan faktor eksternal. ${ }^{48}$ Faktor internal terjadi akibat kesalahan pada pihak bank, disatu sisi resiko ini dapat bersumber dari berbagai aktivitas fungsional bank seperti penyaluran pinjaman, kegiatan tresuri dan investasi, dan kegiatan jasa pembiayaan perdagangan, yang tercatat dalam buku bank. Faktor eksternal terjadi akibat kesalahan pada pihak debitur, resiko ini timbul karena kinerja satu atau lebih debitur yang buruk. Kinerja debitur yang buruk ini dapat berupa ketidak mampuan atau ketidak mauan debitur untuk memenuhi sebagian atau seluruh perjanjian kredit yang telah disepakati bersama sebelumnya.

Faktor internal terjadi dikarenakan kelalaian pihak bank atau AO selaku karyawan pembiayaan. Adapun faktor-faktor yang menyebabkan pembiayaan bermasalah terjadi adalah sebagai berikut: ${ }^{49}$

a) Kurangnya maintenance yang telah diamanahkan

Proses pengawasan atau monitoring seharusnya tetap diperketat, karena setelah dana debitur cair guna meminimalisir hal-hal yang tidak diharapkan. Sehingga dapat menekan tingkat pembiayaan

46 Rima Cahya, Ahmad Mifdhol, "Analisis Pengaruh NPF, FDR, BOPO, CAR dan GCG terhadap Kinerja Keuangan Bank Umum Syariah di Indonesia", Jurnal Bisnis, Vol. 6, No. 1, Juni (2018), 94-117.

${ }^{47}$ Bank Syariah Bukopin, Laporan Keuangan Tahunan 2019, ..., 16 November 2020.

${ }^{48}$ Kasmir, Dasar-dasar Perbankan ..., 96.

49 Trisadini P. Usanti, Transaksi Bank Syariah ..., 105. 
bermasalah yang terjadi apabila calon debitur menyalahgunakan pembiayaan yang telah diberikan. Berbagai kebijakan telah diterapkan dan sedikit mempersulit gerak debitur. Hal ini dilakukan demi kemslakhatan Bersama, yakni masalah yang tidak diinginkan oleh pihak bank dan debitur.

b) Kurangnya ketepatan dalam menganalisa usaha

Terdapat hal-hal yang dijadikan acuan oleh pihak bank, akan tetapi tetap saja ada kendala yang menghambat kinerja pribadi. Hal tersebut mengenai karakter usaha debitur pada data pribadi atau KTP Palsu dan legalitas usaha. Usaha yang dijalankan debitur hanya tipuan, pihak salah mengartikan dan tertipu pada saat survei tempat usaha. Pada keuangan dalam memberikan jumlah pembiayaan juga tidak sesuai dengan permintaan. Kesalahan dalam perhitungan dan pengambilan agunan yang diserahkan debitur. Pemahaman mengenai kondisi ekonomi akan prospek usaha dimasa yang akan datang dengan kebijakan pemerintah yang berlaku. Dan penyelewengan dalam penerapan hukum islam, syariat ataupun kebijakan islam demi memenuhi target pembiayaan.

c) Kurangnya pemahaman kebutuhan yang diperlukan

Pada saat survei dan wawancara terkadang $\mathrm{AO}$ salah mengartikan kebutuhan dan maksud debitur. Sehingga saat pembiayaan telah diberikan tidak bisa sejalan dengan kebutuhan debitur dan mengakibatkan pembiayaan macet terjadi.

d) Kurangnya pencantuman persyaratan

Persyaratan yang dicantumkan wajib diinformasikan dengan detail dan teiliti. Tapi, pada pihak bank terkadang lalai dan menyepelehkan persyaratan yang belum terpenuhi. Hal ini berpengaruh pada pembiayaan karena berhubungan dengan jalannya pembiayaan pada kurun waktu yang telah ditetapkan. 
e) Kurangnya kebijakan yang sehat

Setiap kebijakan yang dijalankan memiliki kekurangan dan kelebihan. Adapun pihak bank menjalankan tugasnya dengan kebijakan yang tidak sehat. Kebijakan tersebut dilakukan dengan menambah persyaratan atau hal-hal yang tidak termasuk pada kebijakan bank syariah demi kepentingan pribadi.

f) Kejar target

AO selaku karyawan pembiayaan memiliki target minimum setiap bulan ataupun tahunnya. Dengan kata lain AO mengambil semua permohonan pembiayaan tanpa melihat analisa pemberian pembiayaan pada calon debitur.

Faktor eksternal terjadi dikarenakan kecurangan debitur selaku penerima pembiayaan. Adapun faktor-faktor yang menyebabkan pembiayaan bermasalah terjadi adalah sebagai berikut: 50

a) Bencana alam

Hal ini terjadi karena keadaan lingkungan atau alam dan tidak ada yang bisa mengetahui. Kejadian ini bisa mengakibatkan usaha debitur tidak berkembang atau gagal.

b) Usaha menurun

Pada usaha calon debitur terdapat beberapa menerapkan sistem hutang dan dikarenakan adanya beberapa konsumen lalai dalam melunasi hutang maka usaha debitur menurun.

c) Tingkat persaingan yang ketat

Dalam perekonomian sudah sewajarnya persaingan akan usaha. Hal ini dikarenakan kondisi ekonomi yang terus berkembang. Sehingga persaingan usaha serupa semakin banyak.

d) Agunan 120.

50 Muchdarsyah Sinungan, Manajemen Dana Bank, (Jakarta: PT Bumi Aksara, 2000), 
Pembayaran kedua melalui agunan terjadi akibat kegagalan dalam pembiayaan atau bencana yang dialami oleh debitur. Sehingga omset menurun dan pembiayaan bermasalah terjadi. Debitur melunasi pembiayaan menggunakan pelelangan agunan yang telah diserahkan.

e) Tingkat pendidikan yang rendah

Debitur juga bisa mengambil pembiayaan atas golongan menengah kebawah. Dan biasanya golongan menengah kebawah banyak yang mengalami tertinggalnya pendidikan. Hal tersebut bisa mempengaruhi kinerja usaha debitur karena kurangnya pengetahuan yang memadai.

f) Keluarga

Pada faktor keluarga debitur bisa mengalami keadaan dimana adanya kepentingan keluarga seperti pernikahan, pengajian atau acara besar lainnya. Disisi lain dari faktor keluarga juga terdapat debitur yang nakal atau curang dengan mempunyai istri/suami simpanan. Sehingga harus membagi kondisi keuangan dengan kepentingan yang tersembunyi.

\section{G. KESIMPULAN}

Dari pembahasan peneliti tentang implementasi early warning system (EWS) dalam menekan tingkat non performing financing (NPF) di perbankan syariah dapat disimpulkan yaitu implementasi yang dapat diterapkan adalah melalui sistem pengukuran peringatan dini bagi bank syariah yang dapat dihitung menggunakan beberapa indikator, yakni meliputi return on equity (ROE), return on asset (ROA), financing to deposit ratio (FDR), non performing finaning (NPF) dan rasio biaya operasional dan pendapatan operasional (BOPO). Berdasarkan hasil dari perhitungan kinerja keuangan menggunakan EWS dapat diambil kesimpulan dari perhitungan ROE, ROA dan FDR kinerja bank dalam kondisi baik. Sedangkan dilihat dari NPF dan BOPO menunjukan kinerja keuangan bank dalam kondisi fluktuasi dengan naik 
turunnya rasio yang tercantum. Disisi lain faktor-faktor yang menyebabkan NPF muncul tergolong pada faktor internal dan eksternal. Faktor internal (pihak perbankan) adalah kurangnya maintenance yang telah ditetapkan, ketepatan dalam menganalisa usaha, pemahaman kebutuhan yang diperlukan, pencantuman persyaratan kebijakan yang sehat dan mengejar terget. Pada faktor eksternal (debitur) adalah bencana alam, usaha menurun, agunan, persaingan jenis usaha bertambah ketat, tingkat pendidikan yang rendah dan faktor keluarga. 


\section{DAFTAR PUSTAKA}

A, Yulya Lukytawati., W., Ranti. (2016). “Faktor-Faktor yang Mempengaruhi Non Performing Financing Pada Bank Umum Syariah Indonesia Periode 2010-2014". Jurnal Al Muzara'ah. Vol. 4, No. 1. 44-60.

Aisyah, Binti Nur. (2015). Manajemen Pembiayaan Bank Syariah. Yogyakarta: Kalimedia.

Antonio, Muhammad Syafi'i. (1999). Bank Syariah Bagi Bankir dan Praktisi Keuangan. Jakarta: Gema Insani dan Tazkia.

Arikunto, Suharsimi. (2010). Prosedur Penelitian; Suatu Pendekatan Praktik. Jakarta: Rhineka Cipta.

Ash-Shiddiqy, Muhammad. (2019). "An Analysis Of Profitability Of Sharia Banks Using Return On Asset (ROA) Ratio And Return On Equity (ROE) Ratio". Jurnal Imara. Vol. 3, No. 2. 117-129.

Bank Syariah Bukopin (BSB). Laporan Keuangan Tahunan 2019. https://www.syariahbukopin.co.id/id/laporan/2019, diakses pada tanggal 16 November 2020.

Cahya, Rima. Mifdhol, Ahmad. (2018). “Analisis Pengaruh NPF, FDR, BOPO, CAR dan GCG terhadap Kinerja Keuangan Bank Umum Syariah di Indonesia". Jurnal Bisnis. Vol. 6, No. 1. 94-117.

Departemen Agama RI. (2005). Al-Qur'an dan Terjemahannya. Bandung: CV. Diponegoro.

Effendi, Jaenal., Thiarany, Usy., Nurmansyah, Tita., (2017). "Factors Influencing Non Performing Financing (NPF) at Sharia Banking". Jurnal Penelitian Sosial Keagamaan. Vol. 25 No. 1. 109-138.

Fatwa Dewan Syariah Nasional No. 07/DSN-MUI/IV/2000 tentang Pembiayaan.

Hanafia, Fifi., Karim, Abdul., (2020). "Analisis CAR, BOP, NPF, FDR, NOM dan DPK Terhadap Profitabilitas (ROA) Pada Bank Syariah di Indonesia". Jurnal Manajemen dan Bisnis. Vol. 2 No. 1. 36-47.

Hariyani, Iswi. (2010). Restruturisasi dan Penghapusan Kredit Macet. Jakarta: PT Elex Media Komputindo. 
Husna, Ade Irvi., Paramansyah, Nurul Arman. (2020). "Perkembangan Industri Perbankan Syariah Pada Pembiayaan Yang Disalurkan". Jurnal Maps (Manajemen Perbankan Syariah). Vol. 3, No. 2. 129-139.

Ilyas, Rahmat. (2019). "Analisis Kelayakan Pembiayaan Bank Syariah". Jurnal Asy Syar'iyyah: Jurnal Ilmu Syari'ah dan Perbankan Islam. Vol. 4, No. 2. 124-146.

Kasmir. (2003). Dasar-dasar Perbankan (Edisi Revisi). Jakarta: Rajawali Pers.

Katiyo. (2004). Analisa Kredit dan Resiko. Jakarta: Institut Bankir Indonesia.

Kuswahariani, Wulandari,. et al. (2020). “Analisis Non Performing Financing (NPF) Secara Umum dan Segmen Mikro Pada Tiga Bank Syariah Nasional di Indonesia". Jurnal Aplikasi Bisnis dan Manajemen. Vol. 6, No. 1. 26.

Marlyna, Diana., Wirando, Mohan Aka. (2018). “Analisa Tingkat Kesehatan Bank Syariah". Technobiz: International Journal Of Business. Vol. 1, No. 1. 19-24.

Nawawi, Ismail. (2010). Manajemen Perbankan dari Teori Menuju Aplikasi. Jakarta: Kencana. . (2011). Perbankan Syariah. Jakarta: Kencana.

Otoritas Jasa Keuangan (OJK). Snapshot Perbankan Syariah Juni 2020. https://ojk.go.id/id/kanal/syariah/beritadankegiatan/publikasi /Pages/Snapshot-Perbankan-Syariah-Juni-2020.aspx, diakses pada 29 September 2020.

Statistik Perbankan Syariah Agustus 2020. https://www.ojk.go.id/id/kanal/syariah/datadanstatistik/statis tikperbankansyariah/Pages/Statistik-Perbankan-Syariah--Agustus-2020.aspx. diakses pada30 September 2020.

Pasal 25 Undang-Undang Republik Indonesia Nomor 23 Tahun 1999 tentang Bank Indonesia.

Pasal 36 Undang-Undang Republik Indonesia Nomor 21 Tahun 2008 tentang Perbankan Syariah.

Remy, Sutan. (2003). Perbankan Islam (Dalam Kedudukan Tata Hukum Di Indonesia. Jakarta: Utama Puataka Grafikia. 
Rivai, Veithzal., Permata, Andria. (2010). Islamic Financial Management. Jakarta: Kencana.

Shaleh, Rahmat. (1980). Kamus Perbankan. Jakarta: Institut Perbankan Indonesia.

Siamat, Dahlan. (2005). Manajemen Lembaga Keuangan : Kebijakan Moneter dan Perbankan Edisi Kelima. Jakarta: Lembaga Penerbit Fakultas Ekonomi Universitas Indonesia.

Sinungan, Muchdarsyah. (2000). Manajemen Dana Bank. Jakarta: PT Bumi Aksara.

Sumandi. (2017). "Analysis an Early Warning System on Sharia Banking Crisis". Jurnal Nisbah. Vol. 3 No. 1. 365-382.

Sulhan M., \& Siswanto, Ely. (2008). Manajemen Bank Konvensional dan Syariah. Malang: UIN Malang Press Cet; 1.

Supriadi, Ismawati. (2020). “Implementasi Prinsip-prinsip Perbankan Syariah Untuk Mempertahankan Loyalitas Nasabah". Jurnal Hukum Ekonomi Syariah. Vol. 3, No. 1. 41-50.

Supriono. (2017). “Analisis Pengaruh Financing To Deposit Ratio (FDR) Terhadap Penempatan Dana Pada SBIS Bank Syariah Di Indonesia". Jurnal Ekonomi Syariah Teori dan Terapan. Vol. 4, No. 7. 531-546.

Usanti, Trisadini P. (2013). Transaksi Bank Syariah. cet. 1. Jakarta: Bumi Aksara.

Usman, Rachmadi. (2001). Aspek-aspek Hukum Perbankan di Indonesia. Jakarta: PT: Gramedia Pustaka Utama.

W, Andi Sri Rezky., Basir, Abd. (2020). “Penerapan Prinsip Bagi Hasil Pada Pembiayaan di Bank Syariah Menurut Undang-Undang Perbankan Syariah". Khatulistiwa Law Review. Vol. 1 No. 1. 61-76.

Yose, Mardiana. Trihantana, Rully. (2017). "Participation and Financing Mechanism Islamic Bank on Syndication". Jurnal Nisbah. Vol. 3, No. 2. 403-423.

Z, A. Wangsawidjaja. (2012). Pembiayaan Bank Syariah. Jakarta: Gramdeia Pustaka. 
Implementasi Early Warning System (Ews)

Zulkifli, Sunarto. (2007). Panduan Praktis Transaksi Perbankan Syariah. Jakarta: Ziktul Hakim. 